\title{
Muellerisphaerids from the Llandovery of western mid-Wales
}

\author{
DAVID K. LOYDELL ${ }^{1}$, IAN MCMILLAN ${ }^{2}$ \& HUGH F. BARRON ${ }^{3}$ \\ ${ }^{1}$ Geology Department, U.C.W. Aberystwyth, Dyfed \\ ${ }^{2} 202$ Tudor Drive, Kingston-on-Thames, Surrey \\ ${ }^{3}$ B.G.S., Keyworth, Nottingham
}

\begin{abstract}
Muellerisphaerids are described and illustrated from Britain for the first time. The mechanical processing method used in their extraction is described. They are preserved as pyrite internal moulds and thus lack the necessary morphological detail (i.e. spines) to be identified to family level. Other microfossils occurring in the samples are also recorded.
\end{abstract}

\section{INTRODUCTION}

Aldridge and Armstrong (1981) applied the informal name mazuelloid to a group of phosphatic, spinose microspheres of unknown affinities from the Silurian of Greenland and Czechoslovakia and the Devonian of Germany. Kozur (1984) created the Order Muellerisphaerida to accommodate these specimens and similar material from the Silurian and Lower Devonian of Hungary. Burrett (1985), Holmer (1987), Priewalder (1987) and Norford and Orchard (1985) have subsequently recognised muellerisphaerids from the Ordovician of Tasmania, the Ordovician of Västergötland (Sweden), the Silurian of Austria and the Silurian of northern Canada respectively.

This paper reports the occurrence of muellerisphaerids, preserved as pyrite internal moulds, from Llandovery mudstones from western mid-Wales. For comparison with these moulds, Figure 1 illustrates the main features of a typical, chemically isolated, complete muellerisphaerid. The central body is hollow and spherical, with a surface which may be smooth, granular or covered with pillars up to $10 \mu \mathrm{m}$ long and $2 \mu \mathrm{m}$ in diameter (see Aldridge and Armstrong, 1981, Fig. 1). Hollow spines are always present, the density of which over the sphere's surface varies considerably between species, as also does their shape, from parallel-sided to conical. Spine terminations are often broadly rounded, but in some species they are irregularly forked. Aldridge and Armstrong (1981) and Kozur (1984) have described the tripartite wall structure, consisting of two outer layers, each less than $1 \mu \mathrm{m}$ thick, composed of crystallites arranged perpendicular to the sphere's surface, and an inner, organic, layer.

\section{MATERIAL AND METHODS}

The material examined consisted of the residues from three mudstone samples collected from the following localities and horizons:

(i) Rheidol Gorge. O. T. Jones (1909) locality F17
(SN754797). Middle Llandovery, Derwenlas Formation (magnus Zone). Black mudstone with abundant pyrite internal moulds of graptolites.

(ii) Hafren Forest. SN842883. Middle Llandovery, Derwenlas Formation (Upper triangulatus or magnus Zone). Black mudstone with pale siltstone stripes - pyrite internal moulds of graptolites abundant.

(iii) Cliffs near Cormorant Rock, Aberystwyth. SN583829. Upper Llandovery, Aberystwyth Grits Formation (most probably turriculatus Zone). Inter-turbidite mudstone disturbed by a network of pyritised burrows.

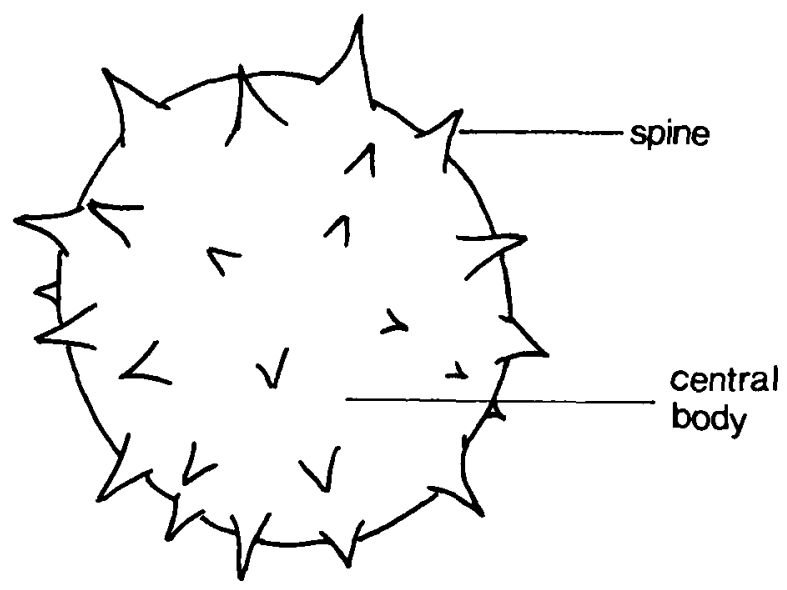

Fig. 1. Main features of a complete muellerisphaerid (based on Priewalder's (1987, Pl. 22, fig. 5) illustration of an unnamed specimen from the Ludlow of the Carnic Alps), $\times 300$. 
The following mechanical processing method was used:

1. Dry lumps of rock were crushed using a steel pestle and mortar. Fines were sieved through a 30 mesh onto a 240 mesh.

2. Any material remaining on the 30 mesh was crushed again.

3. When all the residue was on the 240 mesh sieve the sample was washed slowly and the material on the sieve rubbed between finger and thumb to remove fine grained matter.

4. If any fine grained material still adhered to the pyrite residue the sample was boiled with Quaternary Ammonium Detergent and the rubbing process repeated. (For the particularly indurated sample from O. T. Jones Loc. F17 this process of boiling and rubbing was repeated several times.)

The residues were examined under the light microscope and in the S.E.M.

\section{DESCRIPTION}

The Aberystwyth Grits Formation sample yielded nothing but fragments of burrow and pyrite framboids (Pl. fig. 1).

The samples from the Derwenlas Formation, however, yielded a large number of microfossils all preserved as pyrite internal moulds. These fall into three morphological groups:

1. Smooth spheres (Pl. figs. 2-3) with an average diameter of $100 \mu \mathrm{m}$, some showing evidence of collapse prior to the formation of pyrite (Pl. fig. $3)$. These are of unknown taxonomic status.

2. Muellerisphaerids, $100-150 \mu \mathrm{m}$ in diameter with a variable number of small dome-shaped protuberances (maximum height $<10 \mu \mathrm{m}$ ) regularly spaced over the surface of the sphere (Pl. figs. 4-8). These domes represent infillings of the hollow lower portions of the muellerisphaerids' spines.

3. Spheres, of a similar size to the muellerisphaerids, with a surface broken by a continuous pattern of dome-shaped protuberances (Pl. fig. 9). Whilst these bear a superficial resemblance to framboids, they may be internal moulds either of muellerisphaerids with a rather denser ornament of spines (cf. Aldridge and Armstrong (1981), fig. 1f), or possibly of radiolaria.

\section{DISCUSSION}

This is the first record of muellerisphaerids from the British Isles and the first ever account of this order recovered from mechanically processed Lower Palaeozoic rocks. Previous workers have used chemical isolation methods, for example Aldridge and Armstrong (1981) processed samples using dilute acetic acid, whilst Kozur (1984) used hydrofluoric acid.

In this form of preservation the muellerisphaerids may be distinguished from acritarchs principally by their greater size. The muellerisphaerid calcium phosphate wall, described by Aldridge and Armstrong (1981) and subsequently by Kozur (1984) and Burrett (1985), has not been seen on any specimen. Whether it was lost prior to, or during, processing is not known.

It is interesting to note that all records of muellerisphaerids have so far been from deep-water sediments. Whilst it may be that they were restricted to the planktonic environment of the open sea, it may be that their preservation potential in shallow-water sediments is very low (due to the delicate nature of their skeletons).

Kozur (1984) subdivided the order Muellerisphaerida into two families, the Aldridgeisphaeridae and the Armstrongisphaeridae, the former with broad spines and the latter with narrow spines. Obviously, on the basis of internal moulds it is impossible to decide as to which family the described material belongs as several armstrongisphaerids have broad spine bases before tapering to a much narrower spine termination. Thus it is not possible to augment Kozur's preliminary biostratigraphical observations.

\section{Explanation of Plate}

$$
\text { All } \times 300
$$

Housed at U.C.W. Aberystwyth

Fig. 1. Framboid, Stub UCWG 947 from cliffs near Cormorant Rock (SN583829).

Fig. 2. Smooth sphere, UCWG 946.

Fig. 3. Smooth sphere showing collapse prior to pyrite formation, UCWG 951.

Figs. 4-8. Muellerisphaerids. Fig. 4, UCWG 952. Figs. 5-6, UCWG 948. Figs. 7-8, UCWG 952.

Fig. 9. Sphere with numerous dome-shaped protuberances, UCWG 952.

(Figs. 2, 3, 7-9 from the Hafren Forest (SN842883), Figs. 4-6 from O. T. Jones Loc. F17 in the Rheidol Gorge (SN754797)). 


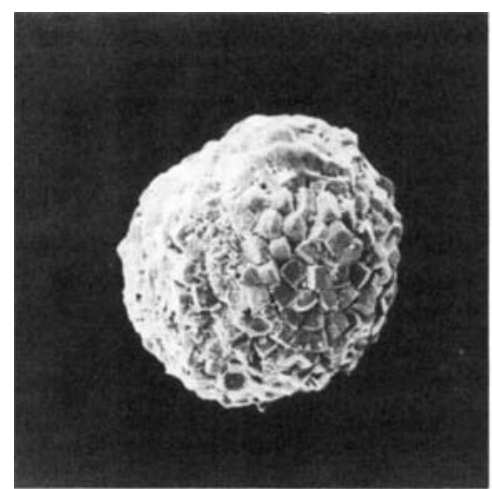

1.



4.

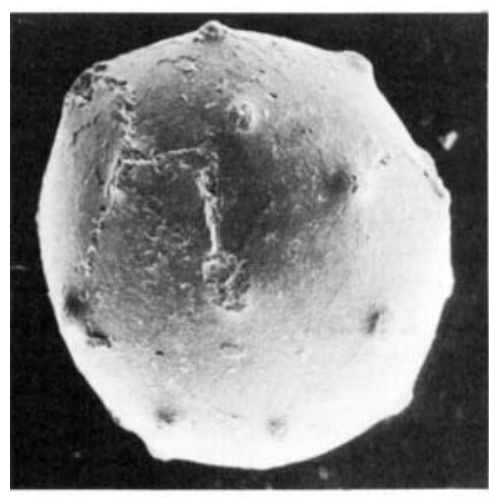

7.



2.
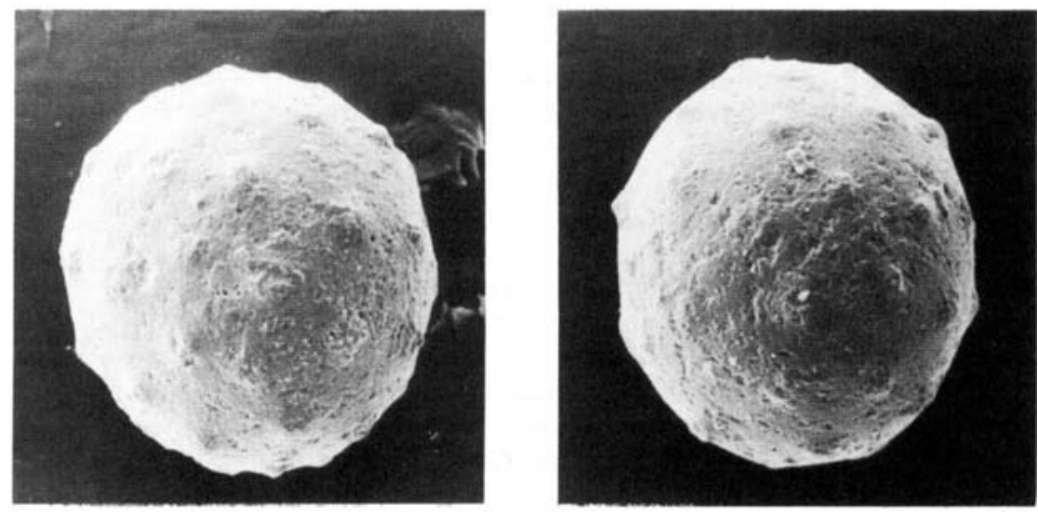

6.
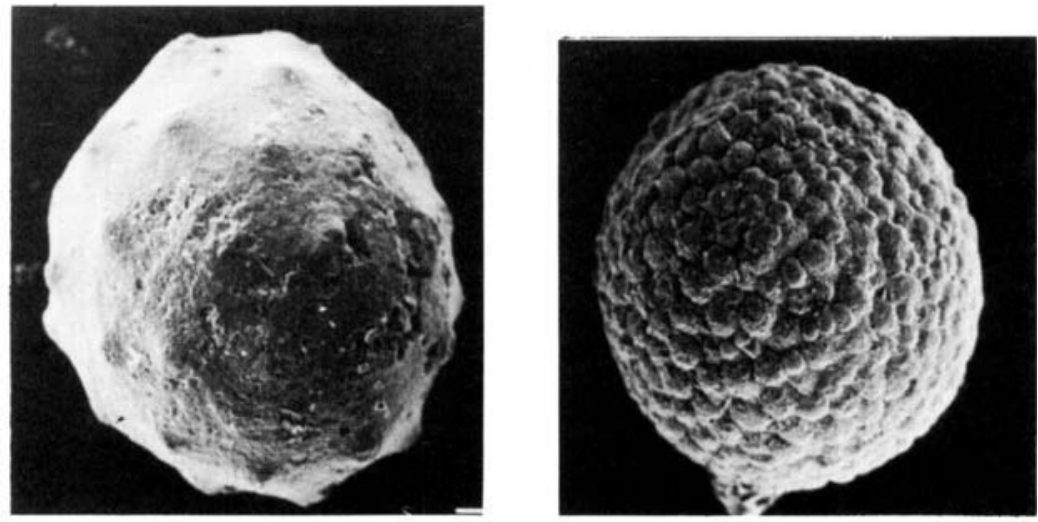

8.

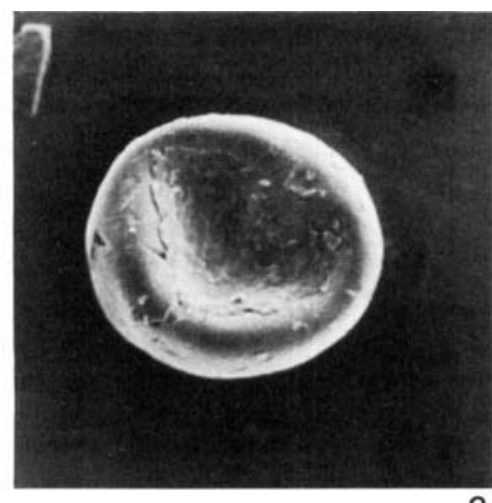

3
9. 


\section{ACKNOWLEDGEMENTS}

Dr. R. J.. Aldridge kindly provided the authors with a translation of the Kozur paper. Mrs. Claire Loydell typed the manuscript. Dr. D. E. B. Bates collected the Rheidol Gorge material. D. Loydell is funded by a U.C.W. Postgraduate Studentship. The contribution to this paper by $\mathbf{H}$. F. Barron arises from participation in the Central Wales Rapid Mapping Project of the British Geological survey (N.E.R.C.) and was published by permission of the Director.

Manuscript received April 1988

Revised manuscript accepted July 1988

\section{REFERENCES}

Aldridge, R. J. \& Armstrong, H. A. 1981. Spherical phosphatic microfossils from the Silurian of North Greenland. Nature, 292, 531-533.

Burrett, C. 1985. Problematic, phosphatic microspheres (mazuelloids) from the Ordovician of Tasmania, Australia. Alcheringa, 9, 158.

Holmer, L. E. 1987. Ordovician mazuelloids and other microfossils from Västergötland. Geol. För. Stockh. Förh., 109, 67-71.

Jones, O. T. 1909. The Hartfell-Valentian succession around Plynlimon and Pont Erwyd (North Cardiganshire). Q. J. Geol. Soc. London, 65, 463-537.

Kozur, H. 1984. Muellerisphaerida eine neue Ordnung von Mikrofossilien unbekannter systematischer Stellung aus dem Silur und Unterdevon von Ungarn. Geol. Paläont. Mitt. Innsbruck, 13, 125-148.

Norford and Orchard, 1985. Early Silurian age of rocks hosting lead-zinc mineralization at Howards Pass, Yukon Territory and District of Mackenzie: local biostratigraphy of the Road River Formation and Earn Group. Geol. Surv. Canada, paper 83-18, 35 pp.

Priewalder, H. 1987, Acritarchen aus dem Silur des Cellon -Profils (Karnische Alpen, Österreich). Abh. Geol. B-A., 40, 1-121. 